\title{
On the aims and scope of the Asia Pacific Journal of Management: What does $A P J M$ really seek to publish?
}

\author{
David Ahlstrom
}

Published online: 12 April 2011

(C) Springer Science+Business Media, LLC 2011

In recent editorial articles in the Asia Pacific Journal of Management (APJM), I noted that $A P J M$ receives numerous submissions that fall outside of our aims and scope, which is to publish theory-based research that advances the understanding of management and organizational success with emphasis on the Asia Pacific region of the world (Ahlstrom, 2010a, b, c). Those editorials were concerned with the main focus of papers as well as related topics such as crafting a paper carefully and positioning it for APJM. Those editorial articles also discussed the characteristics and importance of clear and answerable research questions (Ahlstrom, 2010a), avoiding common problems such as submitting a paper that is outside of the journal's aims and scope, and the related problem of submitting papers that are written for a discipline other than management and organization studies (Ahlstrom, 2010 b, c)_problems that all authors should try to avoid.

\section{Appropriateness for $A P J M$}

Over the years, I have regularly communicated with many editors at conferences to learn of their experiences editing journals and assisting authors in improving their work. I also read widely on editing and reviewing, and the research process in general (e.g., Baruch, Konrad, Aguinis, \& Starbuck, 2008; Starbuck, 2006; Van de Ven, 2007). In doing so, I have found that one of the pet peeves of editors everywhere is that very often, prospective authors do not bother to read the journal's

The Asia Pacific Journal of Management would like to acknowledge Long W. "Rico" Lam (University of Macau), Xu Huang (Hong Kong Polytechnic University), and Dora C. Lau (The Chinese University of Hong Kong) for editing an upcoming APJM Special Issue-Leadership In Asia (2012) and Yuan Lu, Kevin Yuk-Fai Au (The Chinese University of Hong Kong), Erming Xu (Renmin University of China), and Mike Peng (University of Texas at Dallas) for editing a forthcoming Special Issue of $A P J M$-Strategic Management in Private and Family Businesses (2012).

D. Ahlstrom $(\bowtie)$

Department of Management, The Chinese University of Hong Kong, Shatin, NT, Hong Kong e-mail: ahlstrom@baf.msmail.cuhk.edu.hk 
aims and scope before submitting their papers for review. Similarly, many authors seem to barely have read any of the articles in the journal to which they are submitting their papers. Yet these are very important initial steps in organizing a paper and preparing it for submission. By reading the journal's aims and scope, some past papers in the journal, and the editors' lead articles, prospective authors will gain a much clearer understanding of whether APJM (or another journal) is an appropriate outlet for their work (e.g., Ahlstrom, 2010a, b, c).

In addition to this, authors particularly interested in submitting to APJM should watch for editorial and commentary articles in future issues of the journal, particularly in the coming year. These articles will address related research- and paper-crafting topics in more detail including the importance of making contributions to management and international business research and practice (e.g., Colquitt \& Ireland, 2009; Whetten, 1989), some ideas on writing a clearer introduction, and the importance of the paper's literature review (e.g., Ridley, 2008). And as noted, authors should also read several of the journal's published articles to better understand the types of papers $A P J M$ publishes, which come from a range of perspectives, ontologies, and research designs (e.g., Ahlstrom, Lamond, \& Ding, 2009; Ahlstrom, Chen, \& Yeh, 2010; Peng, Li, Xie, \& Su, 2010). Indeed, the recent Special Issues in APJM on corporate governance in Asia (Globerman, Peng, \& Shapiro, 2011) and on managing in ethnic Chinese communities (Ahlstrom et al., 2010), provide a number of excellent examples of the variety of different papers published in APJM. These range from empirical papers to qualitative and exploratory ones, to conceptual papers, and commentaries and reviews (e.g., Dieleman, 2010; Filatotchev, Zhang, \& Piesse, 2011; Globerman et al., 2011; Lin \& Si, 2010; Wielemaker \& Gedajlovic, 2011; Zou, Chen, \& Ghauri, 2010).

It should be clear from the above research and from the other published work in $A P J M$ that manuscripts sent to APJM should generally lie within the domain of management and organizational theory in the Asia Pacific region, and be broadly related to firm success. This is widely defined to mean theory building such as exploratory research on a new or misunderstood topic, theory testing, and theory improvement. Virtually all research designs including empirical studies, quantitative or qualitative data and methods, ethnographies and field research, experiments and quasi-experiments, and mixed methods are welcome (e.g., Creswell, 2008). ${ }^{1}$

\section{Exploratory research}

From the above discussion, it can be seen that there are many different types of papers that are suitable for APJM (Ahlstrom, 2010a). Many authors choose to write and submit fairly standard variance (hypothesis testing) papers to APJM (Van de Ven, 2007). Fewer authors write exploratory or conceptual papers about fairly new phenomena or theory in management and organizations (e.g., Ahlstrom et al., 2009; Lai, Lam, \& Liu, 2010; Young, Peng, Ahlstrom, Bruton, \& Jiang, 2008). Since many (though by no means all) papers in $A P J M$ are variance-type papers, we

\footnotetext{
${ }^{1}$ APJM also publishes papers on methodological, epistemological, and ontological issues and research design (e.g., Ahlstrom et al., 2009).
} 
have received several inquiries from prospective authors asking if $A P J M$ considers exploratory and theory building papers. Just to be completely clear about the answer to that question, APJM certainly does publish exploratory research and welcomes submissions in this area. I wrote two editorial articles in 2010 that also touched (indirectly) on this topic, a topic which bears repeating here (Ahlstrom, 2010a, b). Those articles in 2010 actually commented, however, not on exploratory research specifically, but on the inappropriate or vague use of general verbs such as "examine," "explore," or "investigate" as a substitute for a more proper research question (Ahlstrom, 2010a, p. 4; b, pp. 172-173). Those articles were not, however, addressing the suitability of exploratory research itself for APJM (or any other journal). The point of the sections in those two articles was to encourage authors to commit to clear and answerable research questions, regardless of whatever research design they chose. That is, authors should try to avoid stating that a paper will simply "investigate" or "explore" a topic when they could and should provide a clear and answerable research question. This point has nothing to do with the value of "exploratory research" which is a separate issue of research design and the current state of a research program (e.g., Christensen \& Carlile, 2009; Suddaby, 2006; Van de Ven, 2007). ${ }^{2}$

If one's research were truly exploratory in nature, then perforce the research question should reflect that accordingly. But if you call your research "exploratory," try to be reasonably sure that it truly is exploratory (Christensen \& Carlile, 2009). At $A P J M$ we receive numerous papers that claim to be "exploring guanxi in East Asia," or "examining science and innovation in China." Given that there is some 75 years of academic research on guanxi and related social psychological topics, or that historian Joseph Needham already provided us with about 25 thick volumes exploring the topic of science and innovation in China during the past two millennia should give some pause to any researcher claiming to be conducting an exploratory study of those topics. To be fair, there are still be potential exploratory studies under those two topical areas, but an author would need to work pretty hard to show this through a very careful literature review to justify what still has not been explored about these very well researched areas. Unfortunately, we receive many submissions at $A P J M$ where the author simply writes (usually incorrectly) "there has been little research on this topic" and "our paper will explore this problem." If an author would like to do exploratory research, it is important for that author to be reasonably sure that other researchers have not already explored, defined, specified, and tested the same ground for many years, or if that is the case, try to establish (through the paper's introduction and subsequent literature review) that previous research has

\footnotetext{
${ }^{2}$ We receive a large number of papers at $A P J M$ that simply state they will "explore entrepreneurship in China" or "examine quality control in India." These are very vague statements that barely confine the scope of the analysis; they are not research questions, and they rarely represent true exploratory or grounded research. For example, there has been a large amount of research on entrepreneurship in China in recent years, along with its related topics of family business and business groups (e.g., Carney, Gedajlovic, \& Yang, 2009). An exploratory study on this topic, while certainly possible, would have to be carefully justified and situated in the past literature, of which there is now a great deal. This is a reminder to authors to build a comprehensive understanding of a research program in a certain area in terms of its past literature. If you call something "exploratory," make your utmost effort to be sure it really is exploratory. APJM is certainly interested in receiving good exploratory research.
} 
missed something very important or made some mistake that only grounded theory or some other exploratory research design can identify (e.g., Raman \& Fisher, 1996).

The point of the sections of those two articles in 2010 was to encourage authors to provide clear and answerable research questions, regardless of research designmany examples of good research questions were provided (e.g., Shane, 2008). And authors should avoid writing that his or her paper will simply "investigate" or "explore" a topic when that paper could have instead stated a clear and answerable research question (see Su, Tsang, \& Peng, 2009). This is also why a good literature review is so important to a paper; in the case of an exploratory paper, the literature review makes the case that there has been little research done in that particular area or research site and that the topic is different enough to warrant an exploratory study (Christensen \& Carlile, 2009; Ridley, 2008). This important issue is one that will be addressed in more detail in future $A P J M$ editorials and commentaries.

\section{References}

Ahlstrom, D. 2010a. Publishing in the Asia Pacific Journal of Management. Asia Pacific Journal of Management, 27(1): 1-8.

Ahlstrom, D. 2010b. Clearing the first hurdle at the Asia Pacific Journal of Management. Asia Pacific Journal of Management, 27(2): 171-177.

Ahlstrom, D. 2010c. Avoiding common missteps: Writing papers suitable for the Asia Pacific Journal of Management. Asia Pacific Journal of Management, 27(4): 583-586.

Ahlstrom, D., Chen, S.-J., \& Yeh, K. S. 2010. Managing in ethnic Chinese communities: Culture, institutions, and context. Asia Pacific Journal of Management, 27(3): 341-354.

Ahlstrom, D., Lamond, D., \& Ding, Z. 2009. Reexamining some management lessons from military history. Asia Pacific Journal of Management, 26(4): 617-642.

Baruch, Y., Konrad, A., Aguinis, H., \& Starbuck, W. H. (Eds.). 2008. Opening the black box of editorship. New York: Palgrave MacMillan.

Carney, M., Gedajlovic, E., \& Yang, X. 2009. Varieties of Asian capitalism: Toward an institutional theory of Asian enterprise. Asia Pacific Journal of Management, 26(3): 361-380.

Christensen, C. M., \& Carlile, P. R. 2009. Course research: Using the case method to build and teach management theory. Academy of Management Learning \& Education, 8(2): 240-251.

Colquitt, J. A., \& Ireland, R. D. 2009. From the editors: Taking the mystery out of AMJ's reviewer evaluation form. Academy of Management Journal, 52(2): 224-228.

Creswell, J. W. 2008. Research design: Qualitative, quantitative, and mixed methods approaches, 3rd ed.. Thousand Oaks: Sage Publications.

Dieleman, M. 2010. Shock-imprinting: External shocks and ethnic Chinese business groups in Indonesia. Asia Pacific Journal of Management, 27(3): 481-502.

Filatotchev, I., Zhang, X., \& Piesse, J. 2011. Multiple agency perspective, family control, and private information abuse in an emerging economy. Asia Pacific Journal of Management, 28(1): 69-93.

Globerman, S., Peng, M. W., \& Shapiro, D. M. 2011. Corporate governance and Asian companies. Asia Pacific Journal of Management, 28(1): 1-14.

Lai, J. Y. M., Lam, L. W., \& Liu, Y. 2010. Do you really need help? A study of employee supplication and job performance in China. Asia Pacific Journal of Management, 27(3): 541-559.

Lin, J., \& Si, S. X. 2010. Can guanxi be a problem? Contexts, ties, and some unfavorable consequences of social capital in China. Asia Pacific Journal of Management, 27(3): 561-581.

Peng, M. W., Li, Y., Xie, E., \& Su, Z. 2010. CEO duality, organizational slack, and firm performance in China. Asia Pacific Journal of Management, 27(4): 611-624.

Raman, A., \& Fisher, M. 1996. Reducing the cost of demand uncertainty through accurate response to early sales. Operations Research, 44(4): 87-99.

Ridley, D. 2008. The literature review: A step-by-step guide for students. Thousand Oaks: Sage Publications. 
Shane, S. A. 2008. The illusions of entrepreneurship: The costly myths that entrepreneurs, investors, and policy makers live by. New Haven: Yale University Press.

Starbuck, W. H. 2006. The production of knowledge: The challenge of social science research. New York: Oxford University Press.

Su, Y.-S., Tsang, E. W. K., \& Peng, M. W. 2009. How do internal capabilities and external partnerships affect innovativeness?. Asia Pacific Journal of Management, 26(2): 309-331.

Suddaby, R. 2006. From the Editors: What grounded theory is not. Academy of Management Journal, 49 (4): 633-642.

Van de Ven, A. H. 2007. Engaged scholarship: A guide for organizational and social research. Oxford: Oxford University Press.

Whetten, D. A. 1989. What constitutes a theoretical contribution?. Academy of Management Review, 14 (4): 490-495.

Wielemaker, M., \& Gedajlovic, E. 2011. Governance and capabilities: Asia's entrepreneurial performance and stock of venture forms. Asia Pacific Journal of Management, 28(1): 157-185.

Young, M. N., Peng, M. W., Ahlstrom, D., Bruton, G. D., \& Jiang, Y. 2008. Governing the corporation in emerging economies: A review of the principal-principal perspective. Journal of Management Studies, 45(1): 196-220.

Zou, H., Chen, X., \& Ghauri, P. 2010. Antecedents and consequences of new venture growth strategy: An empirical study in China. Asia Pacific Journal of Management, 27(3): 393-421.

David Ahlstrom (PhD, New York University) is a professor at The Chinese University of Hong Kong. His research interests include management in Asia, innovation and entrepreneurship, and management and organizational history. Professor Ahlstrom has published over 70 peer-reviewed articles in journals such as the Strategic Management Journal, Academy of Management Review, Journal of International Business Studies, Academy of Management Perspectives, Journal of Business Venturing, and Asia Pacific Journal of Management. He also co-authored International Management: Strategy and Culture in the Emerging World. He has guest edited two Special Issues of Entrepreneurship: Theory \& Practice. At APJM, Professor Ahlstrom has also guest edited two Special Issues (Turnaround in Asia in 2004 and Managing in Ethnic Chinese Communities in 2010), and served as a Senior Editor of APJM during 2007-2009, before serving now as Editor-in-Chief. 